Editorial

\title{
The Socio-Economic Integration of Ethnic Minorities
}

\author{
Yaojun $\mathrm{Li}^{1,2, *}$ and Anthony Heath ${ }^{3}$ \\ ${ }^{1}$ Department of Sociology, University of Manchester, Manchester, M13 9PL, UK; E-Mail: yaojun.li@manchester.ac.uk \\ ${ }^{2}$ Cathie Marsh Institute for Social Research, University of Manchester, Manchester, M13 9PL, UK \\ ${ }^{3}$ Nuffield College, Oxford University, Oxford, OX1 1NF, UK; E-Mail: anthony.heath@nuffield.ox.ac.uk \\ * Corresponding author
}

Submitted: 20 March 2017 | Published: 28 March 2017

\begin{abstract}
One of the most striking features of the contemporary world is the scale and complexity of international and internal migration and the rapidly increasing size of indigenous ethnic minorities in the national populations of many countries. International migration continues to be mainly from poor to rich nations but the more recent years have seen migration patterns becoming multidirectional, with migration flows moving between developed countries, amongst developing countries as well as from developing to developed countries. The scale of internal migration in some countries is dazzling. For instance, an estimated 260 million 'peasant workers' have moved to cities in China. The number of indigenous ethnic minorities in the country has also grown substantially, now reaching 106 million. These and other features of population change pose a serious challenge to policy-makers and the general population in many counties, in terms of making and implementing policies of social inclusion for migrant and indigenous ethnic minorities, ensuring equal access to educational and occupational opportunities, and taking measures to facilitate societal acceptance of the ethnic minority groups. With this in mind, we have, in this thematic issue, collected papers that address issues of ethnic integration in both developed and developing countries.
\end{abstract}

\section{Keywords}

ethnic minority; migration; social inclusion; socio-economic equality

\section{Issue}

This editorial is part of the issue "International Migration and Ethnic Integration", edited by Yaojun Li (University of Manchester, UK) and Anthony Heath (University of Oxford, UK).

(C) 2017 by the authors; licensee Cogitatio (Lisbon, Portugal). This article is licensed under a Creative Commons Attribution 4.0 International License (CC BY).

\section{Introduction}

The equal treatment of all social groups in socioeconomic lives is a fundamental principle which is enshrined in the law in many countries. Ethnic minority groups, whether immigrants, their children, or indigenous minorities, have been found to face various disadvantages. In the past few decades, most ethnic studies in Britain, USA, continental Europe and many other parts of the world have tended to focus on 'visible' ethnic minorities who migrate from developing to developed countries in search of a better life for themselves and their children, or asylum seeker trying to flee war-torn zones, famine or political persecution in their home countries. While the disadvantages for many such groups are per- sistent and sustained efforts must be made to assess the causes, manifestations, consequences and possible changes of such disadvantages, new efforts are needed to study both the plights of indigenous ethnic minority groups within the national boundaries, and the integration difficulties faced by less-visible immigrants who move between developed countries and amongst developing countries, which is becoming a more prominent feature in our increasingly globalizing era.

\section{Types of Ethnic Minorities Covered and Challenges for Research}

The ethnic minorities covered in this issue could be put into four broad types. The first type refers to immigrants 
and their children who moved from developing to developed countries. This is the archetypical immigrant group on whom most attention in ethnic studies has been paid. The second type refers to ethnic minorities who are indigenous without immigration histories but who occupy a minority status in the national populations such as in China where, thanks to preferential treatment, they are largely exempted from the family-planning policy and have thus increased their numbers at a much faster rate than the majority population. Yet their economic situation remains disadvantageous due to poverty and harsh local conditions. While some specific, localized, studies have been conducted such as that by Hannum and Xie (1998) on ethnic stratification in the northwestern province of Xinjiang, more comprehensive research on their current socio-economic situation is merited. The third type also pertains to people having a minority status but being not necessarily visible. In the last decade, many individuals have moved between EU countries and they often face issues of 'in-betweenness', being fully integrated in neither their home nor their destination countries and encountering obstacles of social acceptance, as they are often perceived or treated as a 'quasi-ethnic other' (Ryan, Sales, Tilki, \& Siara, 2009). And the fourth type is not necessarily minority in terms of numbers but, being migrant workers, they are not part of what is called the 'charter population' (Heath \& Cheung, 2007, p. 1) and are treated as minorities. An important example is the situation of Arabs in Qatar, who face constant obstacles of social integration even though they share the same religion or language as the Qataris. These differences in minority types pose different challenges in research and the various papers collected in this issue have tried to meet this challenge. Theories developed to explain the situation of one type of migrant worker may well not apply to other types or to indigenous minorities.

As for the first type, namely visible ethnic minority groups, their contemporary socio-demographic development calls for renewed attention to the continued plights they face. Many of the groups, such as those in Britain, came over 60 years ago and their third or even fourth generation has come of age. Many such groups, such as black Caribbeans, black Africans, Pakistanis and Bangladeshis, have suffered decades of disadvantage or discrimination. As many observers (Li \& Heath, 2008, 2010) have noted, immigration is a rather disruptive process, rendering migrants' human and social capital of less or little use in the destination country. Moreover, as many of the immigrants came from poor countries, they did not have much economic capital in the first place. The relative lack of socio-cultural-economic resources, deficient language skills, and direct or indirect discrimination by employers (Wood, Hales, Purdon, Sejersen, \& Hayllar, 2009) all combined to produce disadvantages in employment, occupation and earnings for the first generation. But even the second generation who were born and educated in the destination country and who had better education than the majority group may still be disadvantaged in gaining employment opportunities (Li \& Heath, 2016), a phenomenon aptly termed 'ethnic penalty' (Heath \& Cheung, 2006). What about the third and fourth generations? Lessard-Phillips and Li (2017) provide an analysis of their educational outcomes. They found that the first generation were highly self-selected but the $1.5^{\text {th }}$ generation did poorly due to the disruptive processes of their families' migration (their families were poor upon arrival and they may have opted for the labour market rather than staying in school); however, the second generation outperformed the white British but the third and the fourth generations did not keep up the momentum but rather showed a 'regression to the mean', with education falling to the mainstream average. The educational trajectory over the generations thus suggested some kind of 'integration', but this may well be an incomplete integration as they may not have the same labour market returns to education as do the majority group.

The disadvantages faced by ethnic minority groups and the growing ethnic mixing in local areas have produced new challenges for research: is it the lack of opportunity (area poverty) or ethnic diversity that is mainly responsible for ethnic plights? This question is reminiscent of the 'hunkering down' thesis proposed by Putnam (2007) in trying to explain the declining social trust in the USA. Demireva and Heath (2017) show that neither area deprivation nor area diversity affects whites' employment opportunities but they do have a rather negative impact on ethnic minorities, suggesting that discrimination might be at work. Furthermore, they found that ethnic embeddedness (that is, the concentration of minorities in particular areas) may have reinforced the traditional norms of some ethnic groups, especially among the female members who may, perhaps quite reasonably, think that as there are no jobs around anyway, so why bother looking for one? The poorer chances facing minority groups in Britain find their echo in Australia where Pietsch (2017) shows that skilled immigrants from Asia are much less likely to find themselves in professional-managerial positions than those from Britain or continental Europe.

While personal characteristics and resources, together with employer discrimination, may explain ethnic minorities' disadvantages in capitalist countries such as Britain or Australia, political institutions and social policies may have a mixed effect on indigenous ethnic minorities in China, a state socialist country. On the one hand, the government instigated a household registration (hukou) system in the 1950s, forcing the majority of the population to remain as agricultural workers for life with little hope of upward mobility. On the other, a whole series of preferential policies were practised in favour of the ethnic minorities, exempting them from the strict one-child family policy, requiring lower entrance scores for colleges and universities, preserving cadre positions in government organizations for those from ethnic minority backgrounds within the ethnic au- 
tonomous regions, and promoting economic development with quota recruitment, tax reliefs or loan preferences. How, then, have the two sets of institutional arrangement affected the minorities' life chances? Li and Zhao (2017) show that, for the minorities with urban hukou status, the intergenerational mobility chances are little different from those of the majority but for those with rural hukou, the minorities suffered noticeably, with mobility chances being markedly lower than those of their majority counterparts.

While the foregoing discussed papers that focus on the 'hard' aspects of social inclusion, namely, educational and labour market attainment concerning ethnic minorities in Britain, Australia and China, we also have papers that focus on the 'soft' aspects, such as social acceptance. Diop and colleagues (2017) show that in Qatar where immigrant workers outnumber the citizens, nationals' socio-economic conditions play a minor role whereas trust and bridging social ties have a positive impact on accepting Arabs and Westerners as next-door neighbours, highlighting the role of social capital and social relationships on out-group acceptance.

We also sought a balance between papers using quantitative and qualitative methods, with five in each batch. Konyali and Crul (2017) show that, whilst many second-generation people of Turkish origins have managed to find themselves in elite positions in Germany, they are still faced with an enduring stigma of low status birth, suggesting that gaining social acceptance is difficult even for elites among the ethnic minorities. In a somewhat similar fashion, Rouvoet, Eijberts and Ghorashi (2017) show that Italians in the Netherlands face an identity paradox, feeling isolated in the destination country and being an outsider in the home country. Success requires not only cultural but also identificational integration, a theme echoed by Mattes (2017) on the barriers faced by Muslims in Austria and Germany and by Fernández-Suárez (2017) on immigrant inclusion issues in Spain. And, finally, we include a paper by Hanwei Li (2017) who shows that, contrary to stereotypical images of Chinese students good at 'learning by rote', the students actually benefit more in their studies by constructing bridging social ties in German universities.

Overall, the papers included in the issue have sought to address both issues of enduring sociological significance and emergent ones using a variety of methods as appropriate to the tasks at hand. The papers bring out clearly the multidimensional nature of integration as well as the diversity of integration challenges. Thus, structural integration in terms of success in the labour market may not always be accompanied by social acceptance or identification with the new society. Shared religion or culture does not always lead to parity with respect to other aspects of integration. The major lesson perhaps from this collection is that simple distinctions, such as that between visible and less visible minority groups, can hide more than they reveal. Integration is a complex and dynamic process. The authors include both well- established and younger scholars. We hope that readers will enjoy reading the papers.

\section{Acknowledgements}

We wish to thank all the authors for the painstaking efforts, António Vieira at Social Inclusion for his guidance, patience and support, and the anonymous reviewers for the very insightful comments and suggestions. This thematic issue would not have been possible without their generous support.

\section{Conflict of Interest}

The authors declare no conflict of interests.

\section{References}

Demireva, N., \& Heath, A. (2017). Minority embeddedness and economic integration: Is diversity or homogeneity associated with better employment outcomes? Social Inclusion, 5(1), 20-31.

Diop, A, Li, Y., Al-Ansari, M. M. H. A., \& Le, K. T. (2017). Social capital and citizens' attitudes towards migrant workers. Social Inclusion, 5(1), 66-79.

Fernández-Suárez, B. (2017). The design of migrant integration policies in Spain: Discourses and social actors. Social Inclusion, 5(1), 117-125.

Hannum, E., \& Xie, Y. (1998). Ethnic stratification in Northwest China: Occupational differences between Han Chinese and national minorities in Xinjiang, 1982-1990. Demography, 35(3), 323-333.

Heath, A., \& Cheung, S. Y. (2006). Ethnic penalties in the labour market: Employers and discrimination (DWP Research Report no. 341). London: Department for Work and Pensions. Retrieved from http://research. dwp.gov.uk/asd/asd5/rports2005-2006/rrep341.pdf

Heath, A., \& Cheung, S. (2007). The comparative study of ethnic minority disadvantage. In A. Heath \& S. Cheung (Eds.), Unequal chances: Ethnic minorities in Western labour markets (pp. 1-44). Oxford: Oxford University Press.

Konyali , A., \& Crul, M. (2017). Professionals made in Germany: Employing a Turkish migration background in high-status positions. Social Inclusion, 5(1), 55-65.

Lessard-Phillips, L., \& Li, Y. (2017). Social stratification of education by ethnic minority groups over generations in the UK. Social Inclusion, 5(1), 45-54.

$\mathrm{Li}, \mathrm{H}$. (2017). Academic integration of mainland Chinese students in Germany. Social Inclusion, 5(1), 80-92.

Li, Y., \& Heath, A. (2008). Ethnic minority men in British labour market (1972-2005). International Journal of Sociology and Social Policy, 28(5/6), 231-244.

Li, Y., \& Heath, A. (2010). Struggling onto the ladder, climbing the rungs: employment status and class position by minority ethnic groups in Britain (19722005). In J. Stillwell, P. Norman, C. Thomas, \& P. Surridge (Eds.), Population, employment, health and 
well-being (pp. 83-97). London: Springer.

Li, Y., \& Heath, A. (2016). Class matters: A study of minority and majority social mobility in Britain, 1982-2011. American Journal of Sociology, 122(1), 162-200.

Li, Y., \& Zhao, Y. (2017). Double disadvantages: A study of ethnic and hukou effects on class mobility in China (1996-2014). Social Inclusion, 5(1), 5-19.

Mattes, A. (2017). Who we are is what we believe? religion and collective identity in Austrian and German immigrant integration policies. Social Inclusion, 5(1), 93-104.

Pietsch, J. (2017). Diverse outcomes: Social citizenship and the inclusion of skilled migrants in Australia. Social Inclusion, 5(1), 32-44.

Putnam, R. D. (2007). E pluribus unum: Diversity and community in the twenty-first century, The 2006 Johan Skytte Prize Lecture. Scandinavian Political Studies, 33(2), 137-174.

Rouvoet, M., Eijberts, M., \& Ghorashi, H. (2017). Identification paradoxes and multiple belongings: The narratives of Italian migrants in the Netherlands. Social Inclusion, 5(1), 105-116.

Ryan, L., Sales, R., Tilki, M., \& Siara, B. (2009). Family strategies and transnational migration: Recent Polish migrants in London. Journal of Ethnic and Migration Studies, 35(1), 61-77.

Wood, M., Hales, J., Purdon, S., Sejersen, T., \& Hayllar, O. (2009). A test for racial discrimination in recruitment practice in British cities (DWP Research Report 607). Leeds: Corporate Document Services.

\section{About the Authors}
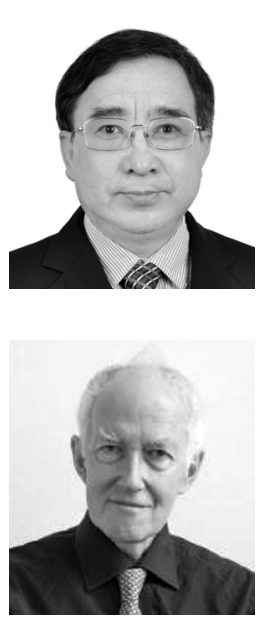

Yaojun Li is Professor of Sociology at the Department of Sociology and the Cathie Marsh Institute for Social Research, Manchester University, UK. His research interests are in social mobility and social stratification, social capital, and the socio-economic integration of ethnic minority groups. He has published widely in these areas, including papers in top sociology journals in Europe and the USA. He has also conducted numerous research projects funded by academic and government agencies in Britain, China, USA, Australia and Qatar.

Anthony Heath (CBE, FBA) is currently Director of the Centre for Social Investigation, Nuffield College, Oxford and Professor of Sociology at CMIST, University of Manchester. His research interests cover social stratification, ethnic inequalities, national identity and social integration. His recent books include Unequal Attainments: Ethnic Educational Inequalities in Ten Western Countries (Proceedings of the British Academy), Migrants and Their Children: Generational Change in Patterns of Ethnic Minority Integration (Routledge), Hard Times: The Divisive Toll of the Economic Slump (Yale) and The Political Integration of Ethnic Minorities in Britain (OUP). He has carried out work for a range of public bodies including OECD, UNDP and a range of government departments in Britain. 